\title{
11. Promoting the human rights of women and girls through developing human rights jurisprudence and advancing the domestication of international human rights standards
}

\section{Background}

In 1988, the Commonwealth Secretariat initiated a series of judicial colloquia to promote the domestic application of internationally and regional agreed human rights norms. Judges at the first colloquium in Bangalore, India, adopted the Bangalore Principles, which call for the creative and consistent development of human rights jurisprudence across the Commonwealth. The principles emphasise the need for practical measures to ensure that international and regional human rights norms, to which many member countries are state parties, are given full effect in national courts. The Bangalore Principles were reaffirmed at subsequent judicial colloquia - Harare, Zimbabwe; Banjul, The Gambia; Abuja, Nigeria; Balliol College, Oxford, UK; and Bloemfontein, South Africa - which focused on different aspects of human rights jurisprudence.

In order to focus on advancing the rights of women and girls through judicial activism, and building on the Bangalore Principles for the development of human rights jurisprudence, the Secretariat organised three regional judicial colloquia between 1994 and 1997. These were held: in Zimbabwe in 1994 for the Africa region, where the Victoria Falls Declaration of Principles for the Promotion of the Human Rights of Women was issued; in Hong Kong in 1996 for the Asia and South Pacific region, where the Hong Kong Conclusions on the domestic application of international human rights norms relevant to women's human rights was declared; and in Guyana in 1997 for the Caribbean region, where the Georgetown Recommendations and Strategies for Action on the Human Rights of Women and the Girl-Child was adopted.

The Commonwealth Plan of Action (PoA) for Gender Equality 2005-2015, which was adopted by Ministers Responsible for Women's Affairs in 2004, and which provides the mandate and remit for the Secretariat's work in promoting the rights of women and girls, recognises that women and girls experience different forms of discrimination during their lives and that gender-based biases, inequalities and inequities intensify their disadvantages. To ensure gender justice, the PoA calls for the employment of gender-sensitive laws, customs/practices and mechanisms. The promotion of active dialogue and 
Part III: From Aspirations to Entitlements

engagement among members of the justice system, religious, cultural, traditional and civil institutions and communities is a key recommendation.

The PoA identifies the addressing of the marginalisation of indigenous women, the combating of trafficking in women and girls, the enactment and implementation of genderresponsive laws, and promotion of human rights standards, particularly, CEDAW, as other key issues for advancing women's rights.

The Gender, Human Rights and Law section of the PoA received the support of law ministers in 2005. Given this endorsement, there is close collaboration between the Gender Section and the Justice Section of the Secretariat to implement the PoA.

In bringing together the Bangalore Principles, the Victoria Falls Declaration, the Hong Kong Conclusions, and the Georgetown Recommendation and Strategies, along with information on key initiatives supported by the Secretariat, this section demonstrates the implementation of the spirit and intent of the declarations and strategies.

\section{Bangalore Principles, 1988}

1. Fundamental human rights and freedoms are inherent in all humankind and find expression in constitutions and legal systems throughout the world and in the international human rights instruments.

2. These international human rights instruments provide important guidance in cases concerning fundamental human rights and freedoms.

3. There is an impressive body of jurisprudence, both international and national, concerning the interpretation of particular human rights and freedoms and their application. This body of jurisprudence is of practical relevance and value to judges and lawyers generally.

4. In most countries whose legal systems are based upon common law, international conventions are not directly enforceable in national courts unless their provisions have been incorporated by legislation into domestic law. However, there is a growing tendency for national courts to have regard to these international norms for the purpose of deciding cases where the domestic law - whether constitutional, statute or common law - is uncertain or incomplete.

5. This tendency is entirely welcome because it respects the universality of fundamental human rights and freedoms and the vital role of an independent judiciary in reconciling the competing claims of individuals and groups of persons with the general interests of the community.

6. While it is desirable for the norms contained in the international human rights instruments to be still more widely recognised and applied by national courts, this process must take fully into account local laws, traditions, circumstances and needs. 
Part III: From Aspirations to Entitlements

7. It is within the proper nature of the judicial process and well-established judicial functions for national courts to have regard to international obligations which a country undertakes - whether or not they have been incorporated into domestic law - for the purpose of removing ambiguity or uncertainty from national constitutions, legislation or common law.

8. However, where national law is clear and inconsistent with the international obligations of the state concerned in common law countries, the national court is obliged to give effect to national law. In such cases, the court should draw such inconsistency to the attention of the appropriate authorities since the supremacy of national law in no way mitigates a breach of an international legal obligation, which is undertaken by a country.

9. It is essential to redress a situation where, by reason of traditional legal training, which has tended to ignore the international dimension, judges and practising lawyers are often unaware of the remarkable and comprehensive developments of statements of international human rights norms. For the practical implementation of these views, it is desirable to make provision for appropriate courses in universities and colleges, and for lawyers and law enforcement officials; provision in libraries of relevant materials; promotion of expert advisory bodies knowledgeable about developments in this field; better dissemination of information to judges lawyers and law enforcement officials; and meetings for exchanges of relevant information and experience.

10. These views are expressed in recognition of the fact that judges and lawyers have a special contribution to make in the administration of justice in fostering universal respect for fundamental human rights and freedoms.

Participants at the Bangalore Colloquium, India, 1988

\begin{tabular}{ll}
\hline Australia & Justice Michael D Kirby, CMG \\
India & Justice P N Bhagwati (Convenor) \\
& Justice M P Chandrakanataraj Urs \\
Malaysia & Tun Mohamed Salleh Bin Abas \\
Mauritius & Justice Rajsoomer Lallah \\
Pakistan & Chief Justice Muhammad Haleem \\
Papua New Guinea & Deputy Chief Justice Sir Mari Kapi \\
Sri Lanka & Justice P Ramanthan \\
United Kingdom & Recorder Anthony Lester, QC \\
United States of America & Judge Ruth Bader Ginsburg \\
Zimbabwe & Chief Justice E Dumbutshena \\
\hline
\end{tabular}


Part III: From Aspirations to Entitlements

\section{Kenya Women Judges Association's initiative on jurisprudence of equality programme}

The Kenya Women Judges Association (KWJA), an affiliate of the International Association of Women Judges, promotes jurisprudence of equality through:

- Creating an enabling environment for accessing the courts and responsive justice for all,

- Facilitating skills and knowledge enhancement for judicial officers on human rights and gender, and

- Advocating for equal representation within the judiciary and building solidarity among judicial officers.

The Commonwealth Secretariat has supported the KWJA through a grant to strengthen its jurisprudence of equality programme. This has enabled ongoing development of a comprehensive curriculum on the jurisprudence of equality, which will be piloted. The curriculum will form the basis of KWJA's training of judicial officials in the country. KWJA hopes to advocate for the curriculum's adoption into the syllabus of the judicial training institute of Kenya.

The Association will also develop information and communication materials, which will include compiling good judgments decided in the lower court by judicial officers who have undergone the training on jurisprudence of equality.

\section{Victoria Falls Declaration, 1994}

1. The participants reaffirmed the principles stated in Bangalore, amplified in Harare, affirmed in Banjul, confirmed in Abuja, reaffirmed at Balliol, Oxford and reinforced at Bloemfontein. These principles reflect the universality of human rights - inherent in men and women - and the vital duties of an independent judiciary in interpreting and applying national constitutions and laws in the light of those principles. These general principles are applicable in all countries, but the means by which they become applicable may differ.

2. The participants noted that all too often universal human rights are wrongly perceived as confined to civil and political rights and not extending to economic and social rights, which may be of more importance to women. They stressed that civil and political rights and economic and social rights are integral and complementary parts of one coherent system of global human rights.

3. The participants were aware that universal human rights are usually interpreted as applying to regulate the public sphere. Violations of human rights in the private sphere, including the family - the site of much of women's experience of violations - are usually perceived to be outside the reach of the human rights. The participants noted that although the state does not usually directly violate women's rights in the private sphere, it often supports or condones an exploitative family structure through various laws and rules of behaviour which legitimate the authority of male members over the lives of female members of the family and, in any event, the 
Part III: From Aspirations to Entitlements

state often fails to act to protect women from private violations or tolerates or, indeed, encourages, a structure wherein private violations occur all too frequently.

4. The participants recognised that many of the existing international and regional human rights standards were formulated within a primarily male perspective and with insufficient gender sensitivity, and sometimes fail to provide protection for the gender-specific interests of women. The participants emphasised the urgent need for the formulation of further specific rights for women, particularly in the economic and social field. The participants stressed the vital need for women to be centrally involved in decision-making at all levels.

5. The participants recognised that discrimination against women can be direct or indirect. They noted that indirect discrimination requires particular scrutiny by the judiciary. The participants, further, emphasised the need to ensure not only formal, but also substantive equality for women and, for that purpose, affirmative action may be adopted if necessary.

6. The participants noted that although international human rights are inherent in all human kind, very often such rights are perceived to be owned, only or largely, by men. The participants emphasised, as did the 1993 United Nations World Conference on Human Rights, that the human rights of women are as valuable as the human rights of men.

7. The participants recognised that international human rights instruments, both generally and particularly with reference to women, and their developing jurisprudence enshrine values and principles long recognised as essential to the happiness of humankind. These international instruments have inspired many of the constitutional guarantees of fundamental rights and freedoms within and beyond the Commonwealth. These constitutional guarantees should be interpreted with the generosity appropriate to charters of freedom. Particularly, the known discrimination guarantee should be construed purposively and with a special measure of generosity.

8. The participants agreed that it is essential to promote a culture of respect for internationally and regionally stated human rights norms, and particularly those affecting women. Such norms should be applied in the domestic courts of all nations and given full effect. They ought not to be considered as alien to domestic law in national courts.

9. All Commonwealth governments should be encouraged to ratify the Convention on the Elimination of All Forms of Discrimination against Women. Those governments that have ratified the Convention with reservations, should examine the content of those reservations, with a view to their withdrawal.

10. All Commonwealth governments should ensure that domestic laws are enacted or adjusted to conform to international and regional human rights standards. 
Part III: From Aspirations to Entitlements

11. The judicial officers in Commonwealth jurisdictions should be guided by the Convention on the Elimination of All Forms of Discrimination against Women when interpreting and applying the provisions of the national constitutions and laws, including the common law and customary law, when making decisions.

12. The participants agreed with the views expressed in the Vienna Declaration and Programme of Action, encouraging the speedy preparation of an optional protocol to enable individual petition under the Convention on the Elimination of All Forms of Discrimination against Women.

13. All Commonwealth governments should subscribe to the principles contained in the Declaration on Violence Against Women, adopted by the UN General Assembly in December 1993. The participants agreed with the Declaration's classification of violence against women as a form of discrimination and violation of human rights.

14. All Commonwealth governments should offer appropriate assistance to the United Nations Special Rapporteur on Violence against Women.

15. There is a particular need to ensure that judges, lawyers, litigants and others are made aware of applicable human rights norms as stated in international and regional instruments and national constitutions and laws. It is crucially important for them to be aware of the provisions of those instruments, which particularly pertain to women.

16. The participants recognised and recommended that gender-sensitised new initiatives in legal education, provision of material for libraries, programmes of continuing judicial discussion and professional training to lawyers and other interest groups in the protection of the human rights of women and better dissemination of information about developments in this field to judges and lawyers should be undertaken for effective implementation of these principles.

17. The participants emphasised the need to translate the international human rights instruments and the African Charter of Human and Peoples' Rights into local languages, in a form accessible to the people and urged the governments to undertake or support that task.

18. The participants were of the view that the governments should mount extensive awareness campaigns through diverse means to disseminate and impart human rights education and encourage and support efforts by non-governmental organisations in this context.

19. The participants acknowledged the important contribution of non-governmental organisations in the dissemination of information about women's human rights and making women aware of those rights. The participants called upon the governments to acknowledge and support the work of non-governmental organisations in the promotion of the human rights of women. 
Part III: From Aspirations to Entitlements

20. The participants emphasised the need to enable non-governmental organisations to provide amicus curae briefs and other legal advice, assistance and representation to women in cases involving human rights issues. The participants also stressed the need to provide free legal aid and advice to women at state cost for enforcement of their human rights.

21. Public interest litigation and other means of access to justice to litigants, especially women, who wish to complain of violations of their rights should be developed. Non-governmental organisations involved in women's issues should also be permitted to bring violations of human rights of women before the courts for redress.

22. Judges and lawyers have a duty to familiarise themselves with the growing international jurisprudence of human rights, and particularly with the expanding material on the protection and promotion of the human rights of women.

23. Closer links and co-operation across national frontiers by the judiciary on the interpretation and application of human rights law should be encouraged.

24. Law schools should be encouraged to develop courses in human rights, which must include a module on the human rights of women.

\section{Reconciling customary laws with statutory laws and international human rights standards}

\section{The Commonwealth Approach}

The Commonwealth, with its shared histories, including common values of democracy and development, has recognised the importance of laws and legal mechanisms for advancing women's rights through the Plan of Action (PoA) for Gender Equality 2005-2015. The PoA also acknowledges the significance of customary laws and practices in the daily lives of women, men and their communities. Given the entrenched gender biases and discrimination that disadvantage women in the context of culture and the law, the PoA calls for advancing women's rights and interests in the administration of laws, particularly on the reconciliation of customary practices and the law.

The promotion of active dialogues between the national women's machineries, law ministries, the judiciary, traditional chiefs, religious and community leaders, and women's rights' advocates, is a key strategy identified by the PoA. The convening of a series of colloquia on gender, culture and the law speaks to that strategy. The outcomes from the colloquia inform concrete follow-up action in the areas of law reform and administration, and access to justice in both the statutory and customary realms.

The first such colloquium was held in Yaoundé, Cameroon, for the West Africa region in 2006. The second colloquium, for the Asia region, was held in Dhaka, Bangladesh, in 2007, while the third was held for the Southern and East Africa region in Windhoek, Namibia, in 2008. The fourth colloquium was held for the Pacific region in Port Moresby, Papua New Guinea, in early 2010, with the Caribbean colloquium scheduled for 2011. 
Each of the colloquia convened has made concrete recommendations on strengthening of law reform, gender mainstreaming of the administration of laws and customary practices, and facilitating women's access to justice. The Secretariat facilitates work with partners to take forward the recommendations.

In the West Africa region, the Secretariat worked with the Widows Development Organisation (WiDo), a widows' rights group in Enugu, Nigeria, to convene a 'Training of Trainers' workshop that enabled members of the judiciary to dialogue and train traditional and faith leaders to address the sensitive issue of writing wills to ensure the protection of widows' rights to property and money. The Secretariat collaborated with Human Rights Focus, an advocacy group in Cameroon, to work with female and male traditional leaders and the judiciary towards reconciling customary norms and statutory laws governing women's rights to land and their access to justice. Support was also provided to Women in Law and Development in Africa (WILDAF), Ghana chapter, to work towards the implementation of recommendations under gender, human rights and the law theme contained in the PoA 20052015. Future plans for the West Africa region include compilation of a handbook in Pidgin for traditional chiefs and grassroots women on land rights and women's access to justice.

For the East Africa region, the Secretariat worked with the Kenya Women Judges Association and convened a colloquium with the judiciary, provincial administration, local chiefs and land disputes tribunal, for the Rift Valley jurisdiction, in Nakuru. The focus on implementation of the Land Disputes Tribunals Act enabled all stakeholders to discuss ways of ensuring women's rights to land given that 98 per cent of the decisions made under this Act by the Land Tribunals are set aside by the courts resulting in delays, obstruction of women's rights to property and their access to justice. The colloquium increased stakeholder understanding of the law, judicial procedures and women's rights, and impressed upon them the importance of their role in facilitating women's access to justice. Subsequently, the Secretariat is working with Umoja Uaso Women's Group in Samburu, Kenya, to conduct legal literacy training among disadvantaged women on their land rights and skills building on craft development for their economic empowerment. Other plans also include a handbook in Kiswahili for traditional chiefs on women's land rights.

In the Asia region, an expert group meeting is planned with the UN Special Rapporteur on Cultural Rights to identify strategies for reconciling customary norms and practices with statutory laws and human rights standards in order to enable the realisation of women's rights. As the drafting of a model regional legislation/instrument on gender equality, with particular focus on trafficking of women, has also been identified as being useful for policy advocacy, the Secretariat will draw on lessons learned from a review of the CARICOM ${ }^{1}$ model legislation on gender equality to take forward this recommendation.

1. See text box in this chapter entitled Review of CARICOM model legislation on gender equality. 
Part III: From Aspirations to Entitlements

\section{Hong Kong Conclusions, 1996}

1. Having regard to the central place of the Victoria Falls Declaration on the recognition and enforcement of the human rights of women, the participants in the Hong Kong colloquium of judges, lawyers and law academics from the Commonwealth countries of the Asia/Pacific region, reaffirmed the principles of the Victoria Falls Declaration and expressed their commitment to uphold and implement those principles.

2. Recalling the Declaration on the Elimination of Violence against Women, the discussions at the Commonwealth Heads of Government Meeting in New Zealand in 1995, the Beijing Declaration and Platform for Action and the conclusions of the meeting of Commonwealth Law Ministers in April 1996, the participants expressed their deep concern at the large-scale violence against women and the girl child which is taking place in various forms in most countries of the Commonwealth. Violence against women is a manifestation of historical unequal power relations between women and men, which have led to domination over and discrimination against women and is a social mechanism by which the subordinate position of women is sought to be perpetuated. All Commonwealth governments should condemn violence against women and girls as a violation of fundamental human rights, including the right to personal security and the right to be free from discrimination on the basis of sex. No law, custom, tradition, culture or religious consideration should be invoked to excuse violence against women. Judges and judicial officers at all levels should be gender-sensitive and aware of the need to protect women against violence through a proactive interpretation of the law.

3. The participants expressed particular concern at the many forms of violence against women in the family. This violence is widespread, but frequently goes unnoticed and unrestrained because of oppressive social, cultural or religious traditions and values. These factors have led to the subordination of women and continue to dominate social attitudes because of lack of awareness of the basic human rights of women, as well as their economic dependence on men. It is incumbent on law enforcement agencies, the legal profession and the courts to intervene appropriately in relation to violence in the family and not to allow its perpetuation through indifference or inadequate response.

4. Participants recognised the importance of custom, tradition, culture and religion as a part of individual and group identity. They recognised that these concepts were sometimes interpreted so as to be oppressive to women. They stressed the need to preserve and enhance worthy customs, while at the same time discouraging those that have an adverse impact on women and girls.

5. Participants recognised that a majority of the world's refugees and internally displaced persons are women and children, and that these persons are an especially vulnerable group who are frequently denied their basic human rights 
and subjected to violence and sexual exploitation. The importance of judicial sensitivity to gender-specific violations of human rights in dealing with cases relating to physical or mental abuse or claims to refugee status were underlined.

6. Recalling that the 1995 meeting of Commonwealth Heads of Government in Auckland urged all Commonwealth governments to ratify the Convention on the Elimination of All Forms of Discrimination against Women, and underlining the importance of accession, ratification and implementation of this Convention and other human rights treaties to the advancement at the national level of the human rights of women and the girl child, the participants noted that it would be desirable if all states in the region became parties to and implemented the Convention.

7. The participants noted that many opportunities exist for judges and other judicial officers to draw on the Convention on the Elimination of All Forms of Discrimination against Women and other international human rights instruments, so as to interpret and apply creatively constitutional provisions, legislation, the common law and customary law. In so doing, they drew attention to the wealth of decisions from countries with shared jurisprudential traditions where judges had engaged in such creative interpretation and application. The importance of educating the judiciary and the legal profession with respect to international human rights standards and principles relevant to gender issues was stressed, as well as the need for national judiciaries to carry out studies on gender bias in the judicial process.

8. Participants noted that it was important that the judiciary reflect the population it serves. Accordingly, it encouraged the exploration of ways to ensure a gender balance in the judicial system.

9. Participants identified a number of areas where there are clear violations of the human rights of women, which might be addressed by the utilisation of international norms in domestic decision-making. These included, in particular, discrimination in matters of nationality, citizenship, property and inheritance, which has serious implications for the exercise and enjoyment by women of other fundamental human rights. Participants also encouraged the review of legislation to ensure its consistency with international human rights obligations undertaken by individual countries.

10. Noting the complementarity between the Convention on the Elimination of All Forms of Discrimination against Women and the Convention on the Rights of the Child, participants drew attention to the special vulnerability of the girl child to violations of human rights and identified this as a matter requiring particular judicial attention. They noted that the principle of the best interests of the child could be used to promote the full enjoyment by the girl child of her rights.

11. Participants noted that litigation to advance the human rights of women was limited at both the national and international levels. They emphasised women's limited access to the judicial process to enforce their rights, and they proposed the further 
Part III: From Aspirations to Entitlements

development of a number of measures to increase women's access to justice, including legal literacy programmes and assisted legal advice and representation. Participants drew attention to the important role that the media could play in creating an awareness of the human rights of women. They suggested that consideration might also be given to encouragement of representative actions and relaxing traditional limitations on locus standi. They also supported the adoption of an optional complaints mechanism for the Women's Convention.

\section{Review of CARICOM model legislation on gender equality}

The CARICOM model legislation in eight areas, viz., citizenship, domestic violence, equality for women in employment, equal pay, inheritance, maintenance and maintenance orders, sexual harassment and sexual offences, was an initiative of the Women's Affairs Section and the Legal Division of the CARICOM Secretariat. The Commonwealth Secretariat partially funded the project and drafting was carried out between 1989 and 1991. Member governments have successfully used the model legislation as a guide to develop their laws and inform policy arenas. Most notably, the model legislation has informed the Family Law Reform project of the Organization of Eastern Caribbean States (OECS) Secretariat. Non-government organisations, including women's and human rights groups, have also used the model for advocacy.

The Commonwealth Secretariat commissioned a review in 2007 to cover seven areas of the model legislation, as the eighth area of domestic violence has been reviewed by UNIFEM Caribbean and United Nations Economic Commission for Latin America and the Caribbean (UNECLAC). The review enables the Secretariat to assess technical assistance and identify areas for further development. It will also offer insights for a similar initiative proposed for Asia. The review highlighted that while the model laws have influenced specific legislation addressing domestic violence and sexual offences, the existence of the model laws in themselves has not catalysed reform processes. The area of domestic violence legislation is a case in point, where sustained advocacy by women's rights groups has played a key role in bringing about change. The value of advocacy is also reflected by the lack of progress in law reform in areas such as equal pay, where no such sustained lobbying by women's interest groups is evident. The review further demonstrates that long-term advocacy leads to the consideration of reform in legislation on gender equality.

With regard to rapes/sexual offences and sexual harassment, the review shows that while the model laws are fairly comprehensive, clear definition of issues and clarity about procedures would need to be considered for future reforms. In the areas of equality of women in employment and equal pay, the review demonstrates that the definition of discrimination needs to be sharpened and the formal equality addressed in the laws needs to be expanded to include systemic inequalities that may not directly target women at the workplace, but which nonetheless affect women's employment and remuneration. The review noted that in certain Commonwealth jurisdictions, issues such as family responsibilities have been addressed in anti-discrimination legislation. It was further suggested that these model laws have not had much impact in the region, and that work on similar model laws by international agencies would need to be referred to in any reform process. 
Part III: From Aspirations to Entitlements

On maintenance and maintenance orders, the model laws adopt a modern approach to child and spousal support, with gender equity concerns addressed in the determination of costs. However, implementation of orders has posed problems given such factors as migration, the notion of family in the Caribbean context and reconstitution of family units.

The Expert Group Meeting, which examined the review, noted that the model laws have been useful to guide drafting of specific legislation on gender equality. While the model laws have not had a significant catalysing effect on the law reform agenda, the meeting recognised that in cases where law reform was underway, the model laws helped to shape legal policy. The model laws have been drawn on for injunctive remedies. The need for clear procedures was underscored and any future work on model laws would have to consider model regulations, where necessary, to facilitate implementation of laws.

\section{Georgetown Recommendations and Strategies for Action, 1997}

1. The Colloquium reaffirmed the Victoria Falls Declaration of Principles for the Promotion of the Human Rights of Women (1994) and the Hong Kong Conclusions (1996) and commended these to states for acceptance and implementation.

2. The Colloquium welcomed the adoption of the Charter of Civil Society for the Caribbean Community by the Conference of Heads of Government at its eighth inter-session meeting in Antigua and Barbuda in February 1997.

3. The Colloquium underlined the fact that the human rights of women and of the girl child are an inalienable, integral and indivisible part of universal human rights, and they must be taken as forming part of mainstream human rights.

4. The Colloquium expressed concern that civil and political rights have received extensive attention within the mainstream human rights discourse while economic, social and cultural rights have been neglected. This has adversely affected women's concerns.

5. Traditional human rights theory primarily focuses on violations perpetrated by the state. This distinction between state responsibility in relation to public and private acts has contributed to a failure to recognise many violations of women's rights as human rights violations.

6. The Colloquium recognised that the fundamental duty of judges to ensure the fair and due administration of justice requires judges to be alert to manifestations of gender discrimination in the law and in the administration of justice, and to take such measures as lay within their power to redress or eliminate any such discrimination. The Colloquium also recognised that the community's understandings of fairness and equality may evolve over time and that judges had both the power 
Part III: From Aspirations to Entitlements

and responsibility to adapt the common law or interpretations of constitutional provisions to meet the changing circumstances of society. The full enjoyment by women of their human rights could only be realised through the creative interpretation and effective enforcement of these rights by the courts. This can only occur if there is an independent and competent judiciary, which enjoys the confidence of the people it serves.

7. The Colloquium noted with concern that some states in the Commonwealth support or condone an exploitative family structure through various laws and rules of behaviour, which legitimise the authority of the male over the female and fail to protect women from private violations of their rights.

8. The Colloquium emphasised that culture, customary and traditional practices or religion should not be invoked as justification for violations of the fundamental rights and freedoms of women.

9. The Colloquium emphasised the goal of universal ratification of international human rights instruments and relevant international labour conventions, in particular the Convention on the Elimination of All Forms of Discrimination against Women and the Convention on the Rights of the Child. It underlined the obligation of states parties to fully and effectively implement their treaty obligations by bringing their constitutions and domestic law and practice into conformity with these human rights commitments. It also urged those states parties which had entered reservations to conventions to consider their withdrawal.

10. The Colloquium emphasised the utility of international human rights norms to domestic litigation, noting that in general there was no constitutional or other bar to referring to international human rights treaties. Among other uses, these norms might in appropriate cases provide a standard that could be used in order to elucidate the meaning of constitutional guarantees.

11. Both the United Nations Declaration on the Elimination of Violence against Women and General Recommendation 19 of the Committee on the Elimination of Discrimination against Women recognised that violence against women takes many forms. These include domestic violence, rape (including rape within marriage), exploitation of girl children (including the disadvantaged), trafficking in women and girls, violence associated with prostitution and with pornography, dowry deaths, violence in the work place and sexual harassment. The personal, economic and social costs of this violence are enormous. States must take effective measures in accordance with the Convention on the Elimination of All Forms of Discrimination against Women, the Declaration on the Elimination of Violence Against Women, and, where applicable, the Inter-American Convention on the Prevention, Punishment and Eradication of Violence. States parties should fulfil their obligations to prevent and eradicate these and other forms of violence against women, as an indispensable part of the process of eliminating gender discrimination. 
Part III: From Aspirations to Entitlements

12. The Colloquium noted with satisfaction that some countries had enacted legislation addressing domestic violence and other forms of violence against women. The Colloquium recommended that other states in the Commonwealth consider the enactment of similar legislation, and stressed the need for such legislation to be regularly monitored and updated as appropriate.

13. The Colloquium expressed its concern in regard to the commercial sexual exploitation of women and girls, including trafficking for the purposes of prostitution. The Colloquium urged states throughout the Commonwealth to take effective measures to eradicate this phenomenon. These measures could include the enactment of legislation (including appropriate penal provisions), and administrative and other measures such as efforts to rehabilitate and reintegrate into society those subjected to these violations.

14. The Colloquium acknowledged the work that the Commonwealth Secretariat has done in developing publications and training materials relating to human rights, including the human rights of women, and urged the organisation to continue this work.

15. Judges participating in the Colloquium expressed their appreciation for the informative and constructive contribution made to the discussions by representatives of non-governmental organisations and noted the recommendations proposed by them.

\section{Recommendations and strategies for action}

The Colloquium adopted the following recommendations and strategies for action:

\section{Information and publicity activities}

16. States that become parties to international human rights treaties should publicise that fact widely among their community and ensure that copies of the treaties, reports of the country under the treaty and other relevant documentation (where possible in local languages) are made widely available.

17. The Commonwealth Secretariat should ensure that copies of the Convention on the Elimination of All Forms of Discrimination against Women and Assessing the Status of Women: A Guide to Reporting under the Convention on the Elimination of All Forms of Discrimination against Women (2nd ed. 1996) are made available to the judiciary and to the Bar Association in each state of the Commonwealth.

Access to information and exchange of information

18. The Commonwealth Secretariat, the United Nations and its agencies, and other bodies should explore ways of making available to judges, judicial officers and practitioners access to electronic sources of information on human rights, in particular relating to the human rights of women, and should ensure the availability 
Part III: From Aspirations to Entitlements

of basic international and comparative materials in libraries accessible to the judiciary and the profession.

19. Judges in the Caribbean and other Commonwealth countries who render decisions in constitutional human rights cases, in cases in which international instruments are invoked or which significantly advance the rights of women under domestic legislation should, as far as possible, send copies of those decisions to: the Commonwealth Secretariat, for inclusion in the Commonwealth Law Bulletin; Interights, for inclusion, as appropriate, in the Commonwealth Human Rights Law Digest, in the Caribbean, to the CARICOM Secretariat and universities in the region for appropriate publication.

20. The Commonwealth Secretariat and the CARICOM Secretariat should endeavour to ensure that all judges in the Caribbean, as well as in other regions, are provided with access, either in electronic or hard copy format, to the Commonwealth Human Rights Law Digest, the Commonwealth Judicial Journal, the Commonwealth Law Bulletin, and the Law Reports of the Commonwealth and regional publications.

21. Judges, practitioners and academics should be encouraged to submit articles and other material for publication in the Commonwealth Law Bulletin and Commonwealth Judicial Journal and regional publications.

22. The Commonwealth Secretariat and the CARICOM Secretariat should explore ways of developing, either on their own or in conjunction with other suitable bodies or NGOs, a website which would contain human rights and related materials, including material on the gender dimensions of human rights, and which would complement the existing work in this area of bodies such as the United Nations, the ILO and the United Nations High Commissioner for Human Rights.

Judicial studies programmes and continuing legal education on gender issues

23. Gender-sensitive training and information about women's human rights should be provided to the judiciary, lawyers, law-enforcement agencies, court personnel, law students and community leaders. Legal literacy programmes to raise public awareness should also be undertaken.

24. Those bodies involved in judicial education seminars at the international, regional and national level should co-operate in and co-ordinate their activities in order to make best use of limited resources.

25. The Commonwealth Secretariat should explore ways in which the experiences of the two series of Judicial Colloquia on human rights which it had organised might be drawn on in order to ensure that gender issues are fully integrated in any future judicial training in which the Secretariat was involved. 
26. The Commonwealth Secretariat, in liaison with the Commonwealth Magistrates' and Judges' Association (CMJA) and other organisations with expertise in the area, should explore the need for the development of further training materials on international human rights, generally and as they relate specifically to women.

The operation of the legal system and reform of the law

27. The language used in human rights instruments, national legislation and in court proceedings and judgements should be non-sexist, and, as appropriate, genderneutral language should be employed.

28. Where general or specific reviews of the law are undertaken by Law Reform Commissions or other bodies, the terms of reference of such reviews should ensure that the impact of existing and proposed laws on the human rights of women is fully taken into account in the process of review and reform of the law.

Operation of the courts and the court system

29. States should, where possible, put in place information systems for the production of gender disaggregated data on the operation of the courts for research, policy formulation and for planning timely interventions.

30. Notwithstanding the obligation to ensure a fair trial for all, judges and prosecutors are encouraged to be vigilant about the withdrawal of cases in order to ensure that the legal system fully protects the rights of women and girls.

\section{Support services and programmes}

31. States should, where possible, establish a comprehensive legal aid programmes to ensure the availability of legal aid or pro bono legal assistance for court and administrative proceedings in which redress for violations of human rights, including those suffered by women and girls, is sought. States should also establish programmes for counselling of women and girls who have suffered violations of rights, as well as special programmes for offenders.

32. States should establish specially trained units in the police force for the investigation of offences by and against women and girls, the functions of which should include counselling for those who have been subject to abuse.

The use of international and regional human rights procedures

33. Lawyers should consider whether more effective use could be made of applicable international and regional complaint procedures to advance women's human rights, in cases in which a remedy was not available within the domestic system. These procedures include the procedures of the Organization of American States, including those of the Inter-American Commission under the American Declaration of the Rights of Man; the American Convention on Human Rights and the Inter-American Convention on the Prevention, Punishment and Eradication of Violence against 
Part III: From Aspirations to Entitlements

Women (Convention of Belém do Pará); the procedures of the Council of Europe under the European Convention on Human Rights; and the procedure under the First Optional Protocol to the International Covenant on Civil and Political Rights, as well as applicable complaints procedures relating to the implementation of international labour conventions.

\section{Enhancement of regional co-operation and exchange of information}

34. The Commonwealth Secretariat, the CMJA, and other responsible international, regional or sub-regional agencies, should explore, in close collaboration with the judges of each region and taking into account existing institutions and programmes, the desirability of the establishment of a regional judicial studies institute or programme to facilitate continuing judicial education and the exchange of legal material among the judges of the region.

\section{Progressing the realisation of women's rights}

The Secretariat has endeavoured to implement recommendations from the Georgetown Colloquium, which focused on partnership building, compilation of training material, and capacity enhancement towards promoting the rights of women and girls through the mandate and remit of the PoA.

The Secretariat's efforts in the area of gender and human rights build on work carried out in the late 1980s and through to the 1990s. The primary focus during that time was on addressing violence against women (development of the Commonwealth integrated approach to combat violence against women [VAW]), judicial dialogues addressing the human rights of women and the girl child (three key declarations/principles on gender equality, jurisprudence and women's and girls' rights) and development of gender equality legislation (support for the development of model legislation in the areas of citizenship, domestic violence, equality for women in employment, equal pay, inheritance, maintenance and maintenance orders, sexual harassment and sexual offences for the CARICOM region). There was also a focus on CEDAW (a manual for NGOs on report writing). Key manuals and resource material addressing VAW were produced. These focused on police training, curriculum for legal studies, annotated bibliography, regional studies on sexual exploitation of children, use of human rights standards for promoting women's rights and comprehensive manuals to address VAW. Key outputs from this body of work, which provide the basis for current work, are:

- Integrated Approaches to Eliminate Gender-based Violence (2003) London: Commonwealth Secretariat.

- International Women's Rights Cases (2005) Routledge-Cavendish.

- Building on this body of work, in 2004, an expert group meeting on gender and human rights set out priority issues to be addressed. A publication entitled Gender and Human Rights was the main output and it informed the Section on gender, human rights and the law in the Commonwealth Plan of Action for Gender Equality 2005-2015. 
